\title{
İlaç Taşıma Sistemleri Olarak Nanopartiküller Kullanılarak Pasif ve Aktif Tümör Hedeflemelerinin Karşılaştırmalı İncelenmesi
}

\author{
${ }^{* 1}$ Cenk Dağlıŏglu \\ ${ }^{1}$ İzmir İleri teknoloji Enstitüsü, Fen Fakültesi, Moleküler Biyoloji ve Genetik Bölümü, İzmir \\ cenkdaglioglu@iyte.edu.tr \\ Geliş Tarihi: 2017-11-07 Kabul Tarihi: 2017-12-28
}

\begin{abstract}
$\ddot{O} z$
Nanopartikül-aracılı ilaç hedefleme kanser araştırmalarının aktif bir alanı olup, tümör dokusuna özgün antikanser etkinliği artırmada çok önemli bir potansiyele sahiptir. Bu çalışmada, hedefleme verimlilik oranlarının belirlenmesi için pasif ve aktif hedefli nanopartiküllerin tümör hedefleme kabiliyetleri, sırasıyla artmış geçirgenlik ve alıkonma (EPR) etkisi ve biyotin reseptörlerini hedefleme yaklaşımları karşılaştııılarak incelendi. Bunun için, görüntüleme ve tedavi edici özellikleri bir arada barından Fe3O4@SiO2(FITC)-DOX (pasif hedefleme için) ve Fe3O4@SiO2(FITC)-BTN/DOX (aktif hedefleme için) multifonksiyonel nanopartikülleri kullanıldı. Nanopartiküllerin tümör hücrelerindeki birikiminin izlenmesi ve miktarsal ölçümü için floresan mikroskopu ve akım sitometresi kullanıldı. Elde edilen sonuçlar, pasif hedeflemeyle karşılaştırıldığında aktif hedefleme stratejisinin servikal karsinoma HeLa hücrelerindeki nanopartikül birikimini 2 kat gibi önemli bir ölçüde artırdığını gösterdi. Aktif hedefli nanopartiküller, pasif hedefli nanopartikülerden yaklaşık 2.5 kat daha düşük yarımaksimum inhibisyon konsantrasyonu (IC50) değeri ile kanser hücrelerinde daha yüksek sitotoksisite sergiledi. Ayrıca, pasif hedefli nanopartiküllerle karşıllaştırıldığında, aktif hedefli nanopartiküllerin apoptotik hücre sayısını yaklaşık \% 21.1 oranında artırdığı bulundu. Bu gözlemler, aktif tümör hedefli ilaç taşıma sistemlerinin, pasif tümör hedefli ilaç taşıma sistemleri ile karşılaştırıldığında, antikanser ilaçların kemoterapötik etkilerini artırmada daha umut verici olduğunu göstermektedir.
\end{abstract}

Anahtar kelimeler: Kanser, multifonksiyonel nanopartiküller, pasif hedefleme, aktif hedefleme

\section{A Comparative Study of Passive and Active Tumor Targeting Using Nanoparticles as Drug Delivery Systems}

\author{
${ }^{* 1}$ Cenk Dağlığlu \\ ${ }^{1}$ Izmir Advanced Technology Institute, Faculty of Science, Department of Molecular Biology and Genetics, \\ Izmir \\ cenkdaglioglu@iyte.edu.tr
}

\begin{abstract}
Nanoparticle-mediated drug targeting is an active area of cancer research and hold enormous potential in improving anticancer efficacy by providing tumor tissue specificity. Herein, tumor targeting capabilities of nanoparticles between passive targeting approach via the enhanced permeability and retention (EPR) effect and active targeting approach via the biotin receptors were compared to determine targeting efficiency rates. For this reason, Fe3O4@SiO2(FITC)-DOX (for passive targeting) and Fe3O4@SiO2(FITC)-BTN/DOX (for active targeting) multifunctional nanoparticles combining imaging and therapy were used. Fluorescence microscopy and flow cytometry were employed to both visualize and quantify the accumulation of nanoparticles into the tumor cells. The results demonstrated that active targeting strategy considerably enhanced nanoparticle accumulation in the cervical carcinoma HeLa cells with a 2 -fold increase in comparison to passive targeting. Targeted nanoparticles exhibited higher cytotoxicity in cancer cells with an approximately 2.5 -fold better half maximal inhibitory concentration (IC50) value than untargeted nanoparticles. Moreover, it was found that targeted nanoparticles increased the number of apoptotic cells by nearly $21.1 \%$ as compared to untargeted nanoparticles. These observations show that active tumor targeting drug delivery systems could be more promising for enhancing the chemotherapeutic effects of anticancer drugs as compared to passive tumor targeting drug delivery systems.
\end{abstract}

Keywords: Cancer, multifunctional nanoparticles, passive targeting, active targeting

*Sorumlu Yazar: ${ }^{1}$ İzmir İleri teknoloji Enstitüsü, Fen Fakültesi, Moleküler Biyoloji ve Genetik Bölümü, İzmir cenkdaglioglu@iyte.edu.tr 


\section{GíRIşs}

Dokulara moleküler seviyede nüfuz etme özellikleri sayesinde nanopartiküller ilaç taşıma sistemleri olarak, hem diyagnostik hem de terapötik uygulamalarda umut vaat etmektedir [1]. Geleneksel kemoterapötik ajanların çoğu, düşük farmakokinetik profillere sahiptir ve vücuda nonspesifik yayıldıkları için ciddi yan etkiler gösteren sistemik toksisiteye neden olmaktadır [2]. Bundan dolayı, tümör bölgelerini hedefleyebilen ilaç taşıma sistemlerinin geliştirilmesi, hem ilaçların toksik etkisini azaltmak, hem de çoklu ilaç dirençliliğinin önüne geçmek açısından çok önemli bir potansiyele sahiptir [3]. Günümüzde nanopartiküllerin bu potansiyellerinin artırılması için, pasif ve aktif tümör hedefleme stratejileri geliştirilerek geleneksel kemoterapi yan etkilerinin en aza indirilmesi amaçlanmaktadır [4]. Artmış geçirgenlik ve alıkonma (EPR: enhanced permeability and retention) etkisi, bir pasif hedefleme formudur ve çeşitli boyutlardaki nanopartiküllerin (genellikle 10-100 nm) tümör dokularında, sağlıklı dokularda mümkün olmayan şekilde birikmesi sonucu oluşur [5]. Nanopartiküller bu benzersiz özellikleri sayesinde, antikanser ajanların tümör hücrelerine taşınımını mümkün kılmaktadır. Bunun yanı sıra nanopartiküllerin yüzeyleri kanser hücreleri tarafindan aşırı ifade edilen reseptörlere spesifik ligandlarla modifiye edilerek, sağlıklı hücreler yerine kanserleşmiş hücreler daha yüksek afinitede aktif olarak hedeflenebilmektedir [6]. $\mathrm{Bu}$ sayede, nanopartiküller aracılığıyla kanser hücrelerinin içindeki ilaç konsantrasyonları artırılırken, normal hücrelere karşı meydana gelebilecek olan toksik etki minimize edilmektedir.

Tüm canlı hücreler, yaşamlarını sürdürebilmeleri için vitaminlere ihtiyaç duyarlar; fakat hızla bölünen kanser hücreleri, özellikle hızlı büyümelerini sürdürebilmek için belirli vitaminlere daha fazla ihtiyaç duyarlar. Bu nedenle vitamin alımına katılan reseptörler, kanserleşen hücre yüzeylerinde aşırı miktarda ifade edilmeye başlamaktadır [7]. Bu artışlar sayesinde, vitamin-bağlantılı ilaç taşıma sistemlerinin daha yüksek afinitede tümör hücrelerini hedeflemesi sağlanabilmektedir [8]. Vitamin B12, folik asit ve biyotin gibi vitaminler kanserli hücrelerde mitoz bölünme için temel vitaminlerdir ve kanser hücreleri tarafindan hücre yüzeyindeki reseptörleri artan oranlarda ifade edilmektedir [9]. Son zamanlarda yapılan çalışmalarda birçok kanser hücresinde biyotin reseptörlerinin, vitamin $\mathrm{B} 12$ ve folat reseptörlerinden daha fazla ifade edildiği gösterilmiştir [10]. Bu nedenle biyotin reseptörleri nanopartiküllerin aktif hedeflendirilmesinde güçlü potansiyele sahip bir hedefleme biyobelirtecidir.
Bu çalışmada, nanopartiküller aracılığıyla pasif ve aktif tümör hedefleme yaklaşımlarının karşılaştırılması amaçlanmıştır. Bunun için, daha önceki çalışmalarda geliştirilmiş ve karakterize edilmiş biyotin reseptörlerini aktif olarak hedefliyebilen, Fe3O4@SiO2(FITC)-BTN/DOX multifonksiyonel nanopartikülleri ile bir pasif hedefleme formu olan artmış geçirgenlik ve alıkonma (EPR) etkisi için sentezlenen biyotin konjuge olmayan Fe3O4@SiO2(FITC)-DOX multifonksiyonel nanopartikülleri kullanıldı [11-12]. Aktif ve pasif hedefleme için kullanılan bu nanopartiküllerin, antikanser etkinlikleri, insan servikal kanser HeLa hücrelerine karşı göstermiş oldukları (1) hücresel alım, (2) floresan görüntüleme, (3) sitotoksik ve (4) pro-apoptotik etkileri araştırılarak karşılaştırıldı.

\section{MALZEME VE YÖNTEM}

\subsection{Malzeme}

3-(4,5-dimetil-2-tiazolil)-2,5-difeniltetrazolyum bromid (MTT) ve tripsin Sigma-Aldrich Chemicals 'dan, adrimisin (doksorubisin) SABA Pharma 'dan, $\% 10$ fetal bovin serumu (FBS), streptomisin, penisilin, L-glutamik asit, DMEM besi yeri Gibco Life technologies 'den, 7-AAD (7-amino aktinomisin) ve PE-Anneksin-V BD Pharmingen 'den temin edilmiştir. Kullanılan diğer tüm kimyasallar analitik saflıktadır ve denemeler boyunca ultra saf su kullanılmıştır.

\subsection{Hücre Kültürü}

HeLa (insan epitelyal servikal karsinoma) hücre hattı İzmir Yüksek Teknoloji Enstitüsü, Biyoteknoloji ve Biyomühendislik Araştırma ve Uygulama Merkezinden temin edildi. Kanser hücreleri, $10 \%$ (v/v) fetal bovin serumu (FBS), $100 \mu \mathrm{g} / \mathrm{mL}$ streptomisin, $100 \mathrm{U} / \mathrm{mL}$ penisilin ve $2 \mathrm{mM} \mathrm{L}$ glutamik asit içeren DMEM besiyeri içinde kültüre edildi. Kültür, steril koşullar altında 37 oC de, \%5 $\mathrm{CO} 2$ ihtiva eden inkübatörde gerçekleştirildi.

\subsection{Nanopartikülleri Karakterizasyonu}

\section{Sentezi} ve

Fe3O4@SiO2(FITC)-BTN/DOX multifonksiyonel nanopartikülleri (Şekil 1A) kaynakça 11 ve 12 de tarif edildiği gibi daha önceki çalışmalarımızda sentezlendi. Bunun için ilk olarak demir oksit (Fe3O4) çekirdek yapısı $\mathrm{Fe}+2 / \mathrm{Fe}+3$ tuzlarının ortak çöktürülmesi yöntemiyle sentezlendi. Nanopartiküllerin biyouyumluluk ve stabilite kazanması, ayrıca fizikokimyasal metodlarla yüzeylerinin fonksiyonelleştirilebilmesi için, demir oksit çekirdek, silika polimeri ile kapland. Bu amaç için sol-jel kimyasından yararlanıldı ve tetraetil 
otrosilikat (TEOS) ile demir oksit çekirdek kaplanarak Fe3O4@SiO2 nanopartikül yap1s1 oluşturuldu. Daha sonra nanopartiküllerin hücre tarafından alındığının optik olarak izlenebilmesi için, Fe3O4@SiO2 nanopartikül yapısına floresan özelliğine sahip floresin izotiyosiyanat (FITC) enkapsüle edildi. Enkapsülasyon sayesinde, nanopartiküllerin fotokimyasal stabilitesini artırması sağlandı. Bu işlemler sonrasında, in vivo ve in vitro koşullarda takip edilebilen, silika manyetik-floresan [Fe3O4@SiO2(FITC)] nanopartikülleri oluşturuldu. Daha sonra nanopartikül yüzeylerinin biyotin (BTN) ile esterifikasyonu sağlanarak, aktif tümör hedefleme özelliği kazandırıldı. Son adımda ise, doksorubisin (DOX), amin-fonksiyonel nanopartikül yüzeyine schiff-bazı kimyası ile bağlandı. Pasif hedefleme çalışmalarında kullanılan Fe3O4@SiO2(FITC)-DOX multifonksiyonel nanopartiküllerinin (Şekil 1B) sentezinde, nanopartikül yüzeylerinin BTN ile esterifikasyonu haricinde, yukarıdaki tüm işlemler sırasıyla takip edildi. Nanopartiküllerin fizikokimyasal karakterizasyonları, dinamik 1 şı saçılım spektrometresi (DLS), zeta-potensiyeli ölçümü, X1şınları difraksiyon analizi (XRD), Fourier dönüşümlü kızılötesi spektroskopisi (FTIR) ve elektron mikroskobu teknikleri (SEM, STEM ve EDX) ile gerçekleştirildi.
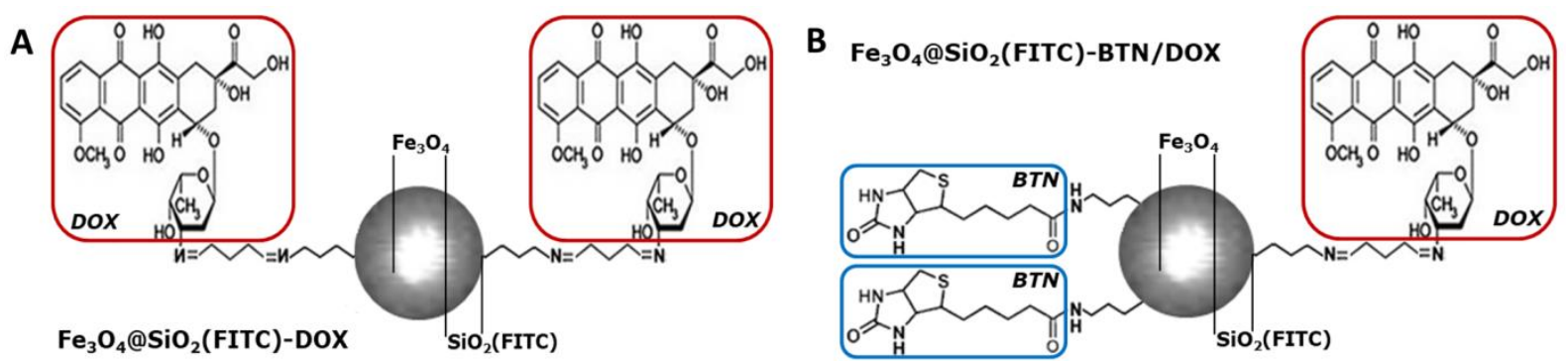

Şekil 1. (A) Fe3O4@SiO2(FITC)-DOX ve (B) Fe3O4@SiO2(FITC)-BTN/DOX nanopartiküllerinin şematik gösterimi. * Nanopartiküllerin çekirdek-kabuk yapısı taramalı-geçirimli elektron mikroskobu (STEM) aracılığıyla elde edildi.

\subsection{Hücresel Alım Deneyleri}

Fe3O4@SiO2(FITC)-DOX ve Fe3O4@SiO2(FITC)-BTN/DOX multifonksiyonel nanopartiküllerinin, HeLa kanser hücrelerini hedefleme potansiyelleri floresan mikroskopu ve akım sitometrisi kullanılarak araştırıldı.

Mikroskopik görüntüleme için, HeLa hücreleri 100.000 hücre $/ \mathrm{mL}$ yoğunluğunda 6 kuyulu $\begin{array}{llll}\text { plakalarda } & 10 & \mu \mathrm{g} / \mathrm{mL} \quad \text { nanopartikül }\end{array}$ konsantrasyonunda 4 saat boyunca inkübe edildi. İnkübasyon sonrası hücreler üç defa fosfat tamponlu çözelti (PBS) ile yıkandıktan sonra, nanopartiküllere enkapsüle edilen FITC floresans mikroskobunda optik olarak izlendi. Nanopartiküllerin hücresel alımı, Olympus IX2-ILL100 floresan mikroskobu kullanılarak görüntülendi. İlgili görüntülerin fotoğrafları CCD kamera kullanılarak çekildi ve ImageJ programı kullanılarak analiz edildi.

Hücresel alım miktarsal analizi için, HeLa hücreleri 200.000 hücre/mL yoğunluğunda 6 kuyulu plakalarda bir gece boyunca inkübe edildi. Daha sonra her bir kuyudaki besiyerleri atıldı ve hücreler yukarıda anlatıldığı gibi nanopartiküller ile inkübe edildi. İnkübasyon sonrası hücreler tripsinize edilerek toplandı ve akım sitometresinde FITC floresanının dağılımı için analiz edildi. Akım sitometrik analizleri, FACS cihazı (Facscanto; Becton Dickinson, San Jose, CA) ile yapıldı.

\subsection{Multifonksiyonel Sitotoksik Etkileri}

Nanopartiküllerin

Fe3O4@SiO2(FITC)-DOX

ve

Fe3O4@SiO2(FITC)-BTN/DOX multifonksiyonel nanopartiküllerinin, HeLa kanser hücreleri üzerinde gösterdikleri sitotoksisite, MTT yöntemi kullanılarak belirlendi.

Sitotoksisite çalışmaları için, HeLa hücreleri 10.000 hücre/mL yoğunluğunda 96 kuyulu plakalarda $0.1 / 0.5 / 1.0 / 10 / 50 / 100 / 200 \mu \mathrm{g} / \mathrm{mL}$ nanopartikül konsantrasyonlariyla ve serbest DOX (100 nM) ile, 48 saat boyunca inkübe edildi. Bu inkubasyondan sonra, hücreler $0.5 \mathrm{mg} / \mathrm{mL}$ MTT içeren ortamda 4 saat inkübe edildi ve ardından plakalar $1800 \mathrm{rpm}$ de 10 dakika boyunca santrifüj edildi. Süpernatant uzaklaştırıldıktan sonra her bir kuyucukda oluşan formazan kristalleri $150 \mu \mathrm{L}$ DMSO içerisinde çözüldü ve $570 \mathrm{~nm}$ deki absorbansları mikroplaka okuyucu aracılığıyla okunarak "yarı-maksimum inhibisyon konsantrasyonları" (IC50) belirlendi. IC50 değerleri GraphPad Prism 7.0 yazılımı ile hesapland1. 


\subsection{Multifonksiyonel Nanopartiküllerin Pro- apoptotik Etkileri}

$\mathrm{Fe}_{3} \mathrm{O}_{4} @ \mathrm{SiO}_{2}$ (FITC)-DOX ve $\mathrm{Fe}_{3} \mathrm{O}_{4} @ \mathrm{SiO}_{2}$ (FITC)BTN/DOX multifonksiyonel nanopartiküllerinin, HeLa kanser hücreleri üzerinde gösterdikleri proapoptotik etkileri ve apoptoza uğrayan hücrelerin yüzdeleri, 7-AAD ve PE-Anneksin-V çift boyama yöntemi ile akım sitometresinde ölçüldü.

Apoptoz çalışmaları için, Hela hücreleri 100.000 hücre/mL yoğunluğunda 6 kuyulu plakalarda $\mathrm{IC}_{50}$ konsantrasyonlarındaki nanopartiküller ile 4 saat boyunca inkübe edildi. İnkübasyon sonrası hücreler, PBS ile yıkandı ve tripsinize edilerek santrifüjle topland. Santrifüj sonrası tekrar PBS içerisinde yıkanan hücreler, $200 \mu \mathrm{L}$ anneksin bağlama tamponu içerisinde çözüldü ve 10 'ar $\mu \mathrm{L}$ 7-AAD ve PE-Anneksin-V ile boyanarak, 15 dakika karanlık ortamda inkübe edildi. İnkübasyon sonrası hücrelerin hepsi ayrı ayrı akım sitometresinde okutularak apoptoz oranları belirlendi.

\section{7. İstatistiksel Analiz}

Tüm veriler, ortalama \pm standart sapma (SS) olarak verildi. İstatiksel analizler Student's t testi kullanılarak Microsoft Excel yazılımı aracılığıyla yapıldı. $\mathrm{P} \leq 0.05$ değeri istatistiksel olarak anlamlı kabul edildi.

\section{SONUÇLAR VE TARTIŞMA}

\subsection{Hücresel Alım}

Fe3O4@SiO2(FITC)-DOX ve Fe3O4@SiO2(FITC)-BTN/DOX multifonksiyonel nanopartiküllerinin HeLa kanser hücrelerini hedefleme potansiyellerinin araştırılması için aydınlık alan ve floresans mikroskop görüntüleri çekildi. Nanopartiküllerin hücresel lokalizasyonları, floresans görüntülerine karşılık gelen aydınlık alan görüntülerinin karşılaştırılmasıyla elde edildi. Her iki nanopartikülün de kanser hücrelerini hedefleyebildiği, fakat aktif hedefli Fe3O4@SiO2(FITC)-BTN/DOX

nanopartiküllerinin hücre içi floresans yoğunluklarının pasif hedefli Fe3O4@SiO2(FITC)DOX nanopartiküllerine oranla daha yüksek olduğu belirlendi. Akım sitometrik analizleri sonucu, Fe3O4@SiO2(FITC)-BTN/DOX nanopartikülleri $\% 86.1$ 'lik düzeyde hücresel alım verimliliği gösterirken, $\quad F e 3 O 4 @ S i O 2(F I T C)-D O X$ nanopartiküllerinin \%45.3 'lük bir hücresel alım verimliliği gösterdiği belirlendi (Şekil 2). $\mathrm{Bu}$ sonuçlar, aktif hedefli nanopartiküllerin pasif hedefli nanopartiküllere göre, kanser hücrelerine daha başarılı bir şekilde nüfuz edebildiğini göstermektedir.

\section{HeLa}
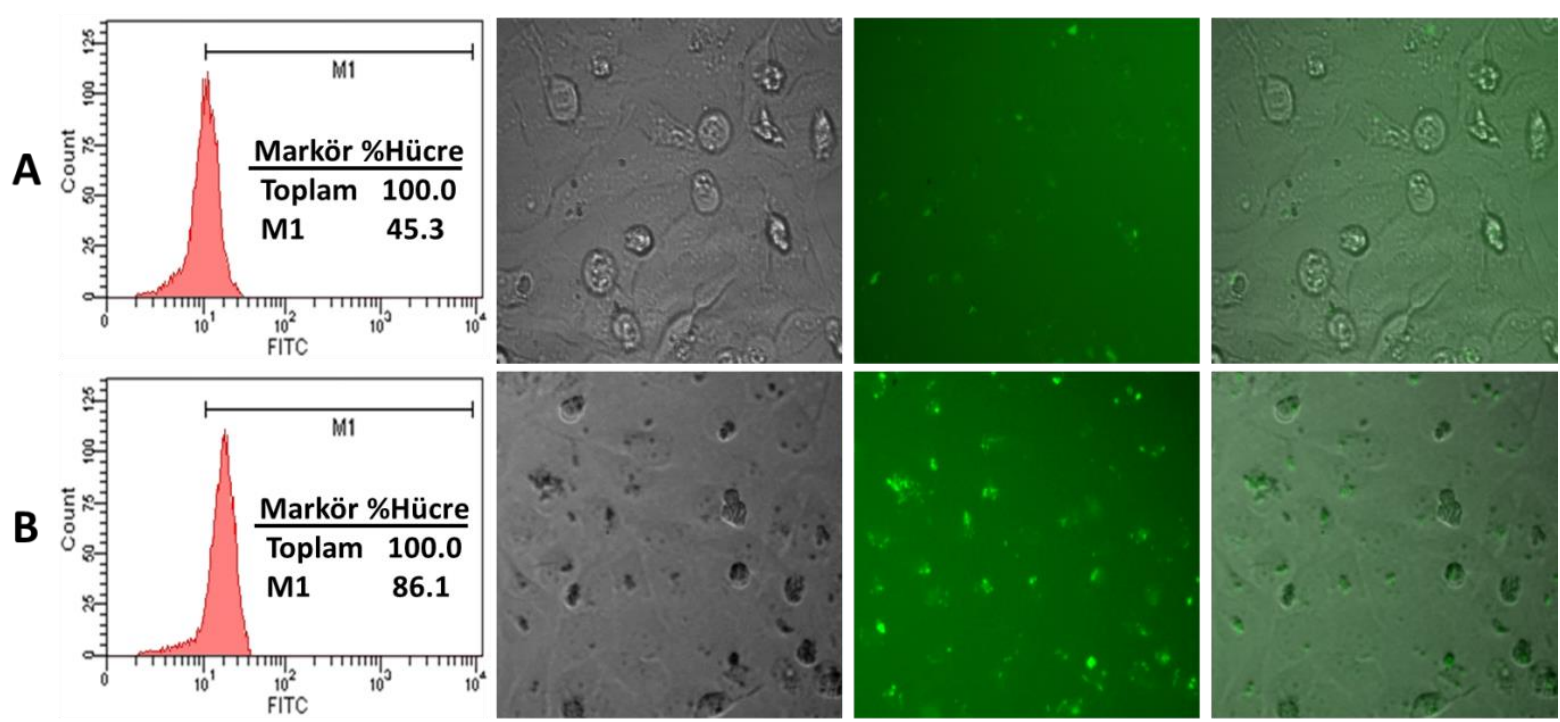

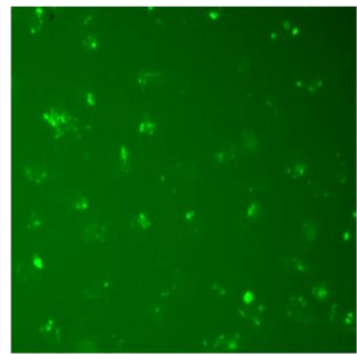

2

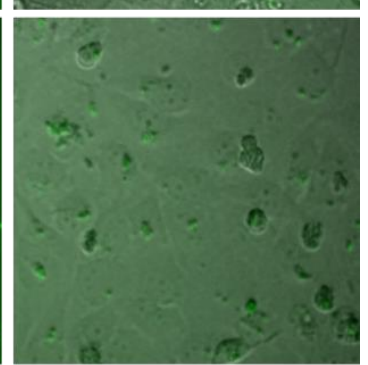

3

Şekil 2.HeLa hücrelerinin (A) Fe3O4@SiO2(FITC)-DOX ve (B) Fe3O4@SiO2(FITC)-BTN/DOX multifonksiyonel nanopartikülleri ile 4 saat inkübasyonu sonrası hücresel alım miktarsal analizi ve floresan mikroskobu görüntüleri. Sütunlar için: 1. aydınlık alan görüntüleri; 2. floresans görüntüleri; ve 3. her iki görüntünün üst üste birleştirilmesi. 


\subsection{Multifonksiyonel} Sitotoksik Etkileri

Nanopartiküllerin

Fe3O4@SiO2(FITC)-DOX

ve

Fe3O4@SiO2(FITC)-BTN/DOX multifonksiyonel nanopartiküllerinin HeLa kanser hücreleri üzerinde nasıl bir sitotoksik etki gösterdiğini incelemek için, MTT hücre proliferasyonu analizi yapıldı. Bunun için, kanser hücrelerine 48 saat boyunca artan konsantrasyonlarda $(0.1-200 \mu \mathrm{g} / \mathrm{mL})$ nanopartiküller ve serbest DOX $(100 \mathrm{nM})$ uyguland. Fe3O4@SiO2(FITC)-BTN/DOX

nanopartiküllerinin, Fe3O4@SiO2(FITC)-DOX nanopartikülleri ile karşılaştırıldığında yaklaşık 2.5 kat daha düşük IC50 değeri ile kanser hücrelerine karşı daha güçlü bir sitotoksik etkiye sahip olduğu bulundu (Tablo 1). Daha ileri sitotoksisite araştırmalarında hücrelere, kemoterapi altındaki hastaların ortalama plazma doksorubisin konsantrasyonunu olan $100 \mathrm{nM}$ serbest DOX [13] uygulandı. Şekil 3 de gösterildiği gibi, sahip oldukları daha düşük DOX konsantrasyonları ile, her iki nanopartikül de serbest DOX tarafindan sergilenenden daha yüksek oranlarda sitotoksisite sergiledi. $\mathrm{Bu}$ sonuçlar aktif hedefli nanopartiküllerin, pasif hedefli nanopartiküllere göre daha yüksek sitotoksik potansiyele sahip olduğunu, fakat her iki ilaç taşıma sisteminin de kemoterapötik ajanın antikanser etkinliğini arttırdığını gösterdi. Benzer bir şekilde daha önce yaptığımız çalışmalarda da, ilaç taşıma sistemleri olarak nanopartiküllerin kemoterapötik ajanların antikanser aktivitelerini, biyokimyasal profilleri birbirlerinden çok farklı olan tümör türevli çeşitli kanser hücre hatlarına karşı arttırdığı gösterilmiştir [14-15].

Tablo 1. $\mathrm{Fe}_{3} \mathrm{O}_{4} @ \mathrm{SiO}_{2}$ (FITC)-DOX ve $\mathrm{Fe}_{3} \mathrm{O}_{4} @ \mathrm{SiO}_{2}$ (FITC)-BTN/DOX multifonksiyonel nanopartiküllerinin HeLa hücrelerindeki 48 saatlik $\mathrm{IC}_{50}$ değerleri. Değerler üç bağımsız denemenin ortalama \pm SS'sını temsil etmektedir.

\begin{tabular}{lc}
\hline Formülasyonlar & IC 5 \\
\hline Fe $_{3} \mathbf{O}_{4} @$ SiO $_{2}$ (FITC)-DOX & $111.3 \pm 7.4 \mu \mathrm{g} / \mathrm{mL}(\sim 87.8 \mathrm{nM}$ konjuge DOX içermekte $)$ \\
Fe $_{3} \mathbf{O}_{4} @$ SiO $_{2}$ (FITC)-BTN/DOX & $43.5 \pm 2.3 \mu \mathrm{g} / \mathrm{mL}(\sim 34.4 \mathrm{nM}$ konjuge DOX içermekte $)$ \\
\hline
\end{tabular}

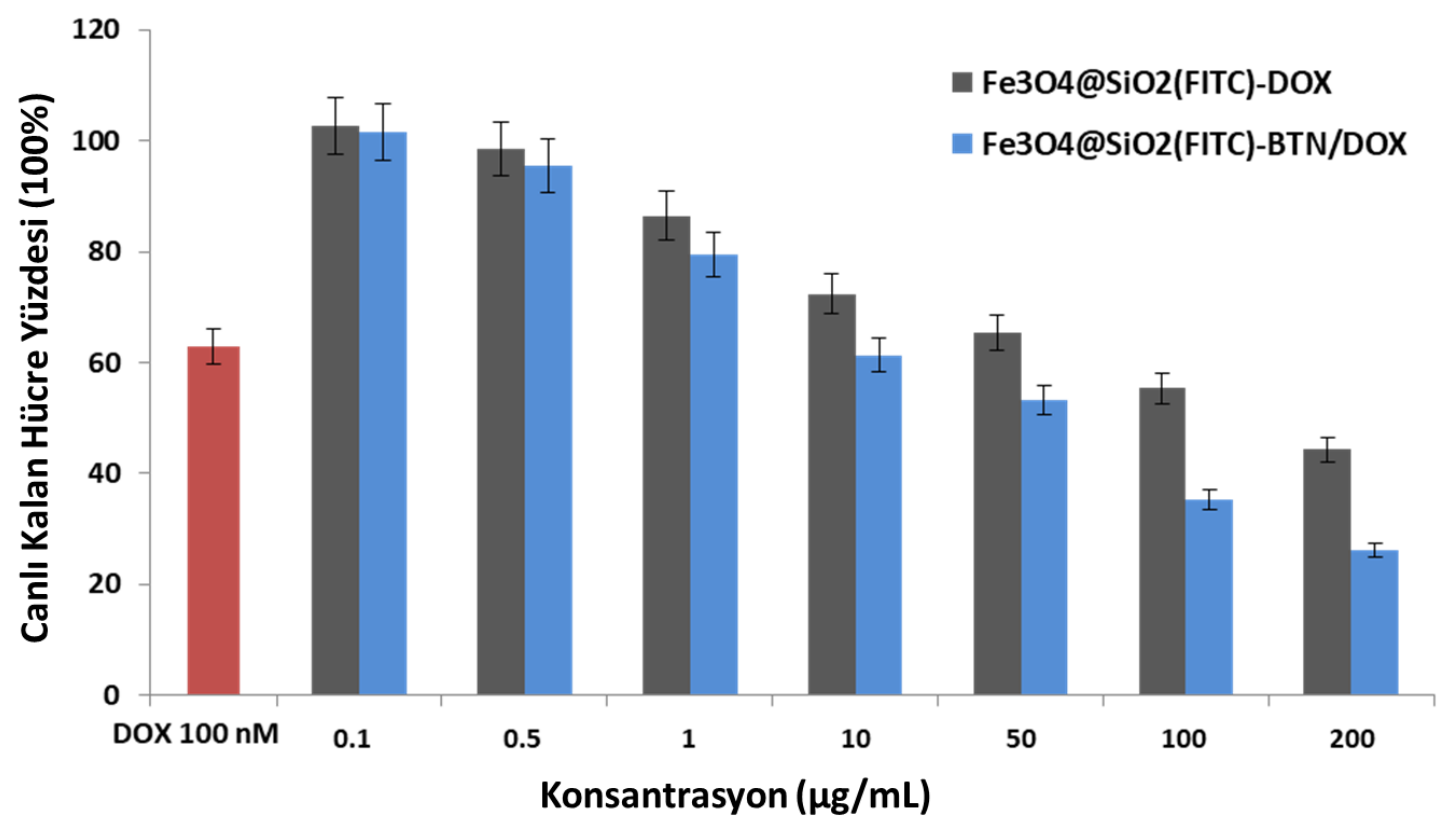

Şekil 3. Serbest DOX, Fe3O4@SiO2(FITC)-DOX ve Fe3O4@SiO2(FITC)-BTN/DOX multifonksiyonel nanopartiküllerinin HeLa hücreleri üzerinde gösterdiği antikanser aktiviteleri. Her bir kolon üç bağımsız denemenin ortalama \pm SS'sin temsil etmektedir.

\subsection{Multifonksiyonel Nanopartikülleri Pro- apoptotik Etkileri}

Fe3O4@SiO2(FITC)-DOX ve Fe3O4@SiO2(FITC)-BTN/DOX multifonksiyonel nanopartiküllerinin, HeLa kanser hücreleri üzerindeki apoptozu indükleme etkileri ve apoptoza uğrayan hücrelerin faz kompozisyonları, 7-AAD ve PE-Anneksin-V çift boyama yöntemi ile akım sitometresinde ölçüldü. Fe3O4@SiO2(FITC)BTN/DOX nanopartikülleri, Fe3O4@SiO2(FITC)DOX nanopartikülleri ile karşılaştırıldığında, kanser 
hücrelerinde çift (PE-anneksin-V/7-ADD) pozitif apoptotik hücrelerin yüzdesini \%34.9 'dan \%57.8 'e artırdı (Şekil 4). Bu sonuçlar göstermektedir ki, aktif hedefli nanopartiküller, kanser hücrelerine daha yüksek oranda kemoterapötik ajan yüklemesi sağlamakta ve bu sayede DOX-aracılı apoptoz oranlarını pasif hedefli nanopartiküllere oranla aynı zaman dilimi içerisinde daha yukarı seviyelere taşımaktadır. Ayrıca bu sonuçlar daha önce raporladığımız, kanser hücrelerinin yüzeyindeki birden fazla reseptörü hedeflemek suretiyle, hücre içi ilaç konsantrasyonlarının artırılabildiğini ve buna bağlı olarak da, daha yüksek apoptotik hücre değerlerine ulaşılabildiğini gösterdiğimiz çalışmamızı da desteklemektedir [12].
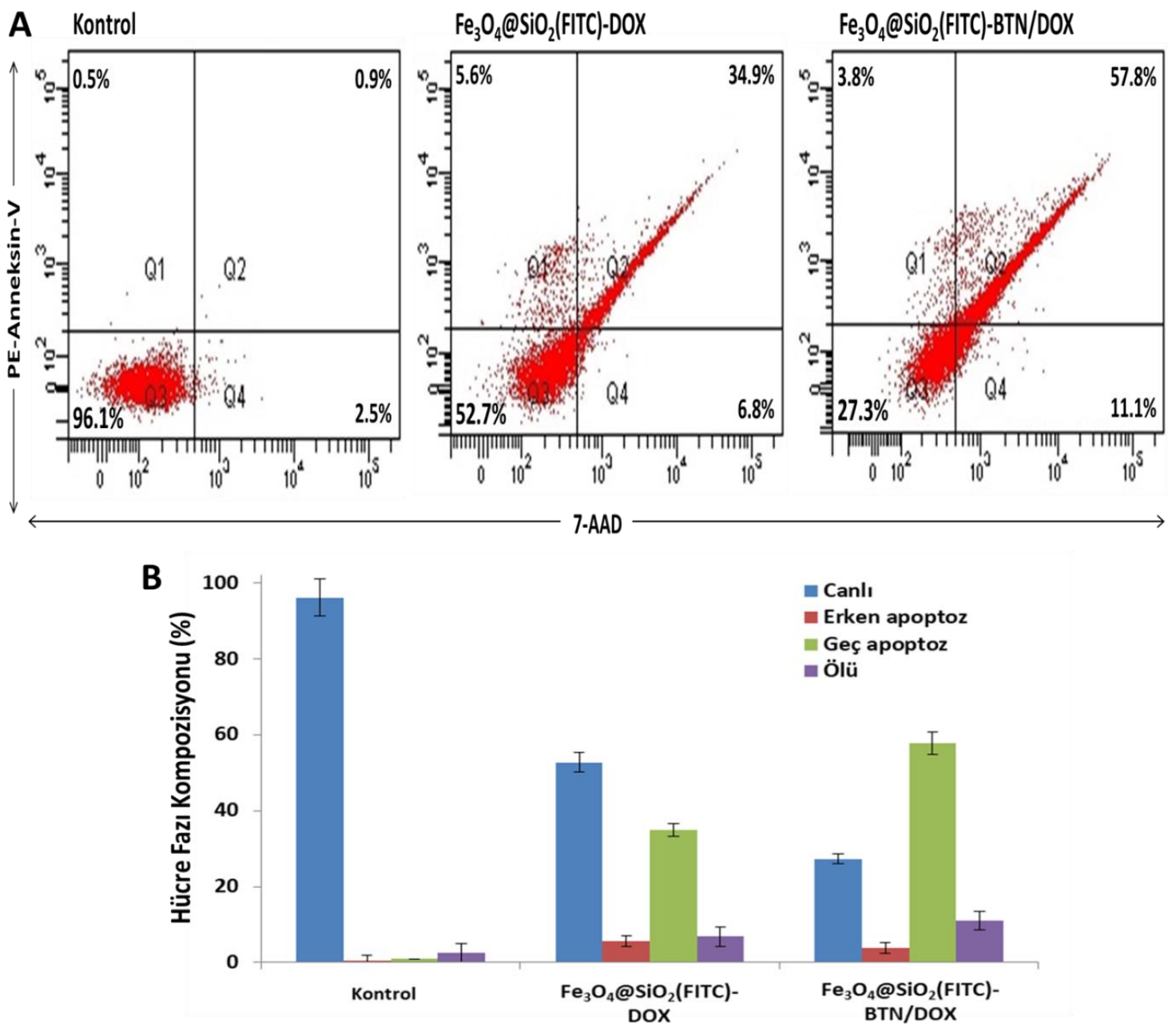

Şekil 4. HeLa hücrelerinin apoptoz analizler. (A) Fe3O4@SiO2(FITC)-DOX ve Fe3O4@SiO2(FITC)-BTN/DOX multifonksiyonel nanopartikülleri ile IC50 konsantrasyonlarında muamele edilen kanser hücrelerinin 7-AAD ve PE-Anneksin-V çift boyama okumaları. Akım sitometresi grafiklerinde, canlı hücreler PE-annexin-V(-)/7-ADD() olarak etiketli, erken apoptotik hücreler PE-annexin-V(+)/7-ADD(-) olarak etiketli ve apoptotik hücreler ise PEannexin-V(+)/7-ADD(+) olarak etiketlidir. (B) Nanopartiküller ile muamele edilen HeLa hücrelerinin faz kompozisyon yüzdesi. Nanopartikül uygulanmayan hücreler kontrol olarak kullanıldı. Her bir kolon üç bağımsız denemenin $(\mathrm{n}=3)$ ortalama \pm SS'sını temsil etmektedir.

\section{GENEL DEĞERLENDİRME}

$\mathrm{Bu}$ çalışmada, ilaç taşıma sistemleri olarak kanser hücrelerini pasif olarak hedefleyebilen Fe3O4@SiO2(FITC)-DOX multifonksiyonel nanopartikülleri ile aktif olarak hedefleyebilen Fe3O4@SiO2(FITC)-BTN/DOX multifonksiyonel nanopartiküllerinin antikanser etkinlikleri karşılaştırıldı. Hücresel alım deneyleri ile her iki nanopartikülün de seçici olarak HeLa kanser hücrelerini hedefleyelebildiği, fakat aktif hedefli nanopartiküllerin hücresel alım kapasitelerinin pasif hedefli nanopartiküllere göre çok daha yüksek olduğu belirlendi. Sitotoksisite ve pro-apoptotik çalışmaları, hücresel alım kapasitelerine paralel bir şekilde aktif hedefli nanopartiküllerin gösterdiği 
antikanser etkinin, pasif hedefli nanopartiküllerden yüksek olduğunu, fakat her iki nanopartikülün serbest DOX'un sergilediğinden daha yüksek bir antikanser aktiviteye sahip olduğunu gösterdi. Bu sonuçlar, aktif hedefli nanopartiküllerin, pasif hedefli nanopartiküllere oranla, kanser tedavisinde daha önemli bir antitümör potansiyele sahip olduğunu göstermektedir.

\section{TEŞEKKÜR}

Akım sitometresi okumalarındaki teknik yardımlarından dolayı İzmir Yüksek Teknoloji Enstitüsü, Biyoteknoloji ve Biyomühendislik Uygulama ve Araştırma Merkezi çalışanı Uzman Özgür Yılmazer 'e en içten dileklerimle teşekkür ederim.

\section{KAYNAKÇA}

[1] L. Y. Rizzo, B. Theek, G. Storm, F. Kiessling and T. Lammers, "Recent progress in nanomedicine: therapeutic, diagnostic and theranostic applications", Curr. Opin. Biotechnol., 24 (6), pp. 1159-1166, 2013.

[2] I. Ojima, X. Geng, X. Wu, C. Qu, C. P. Borella, H. Xie, S. D. Wilhelm, B. A. Leece, L. M. Bartle, V. S. Goldmacher and R. V. J. Chari, "Tumor-Specific Novel Taxoid-Monoclonal Antibody Conjugates", J. Med. Chem., 45, pp. 5620-5623, 2002.

[3] S. Jaracz, J. Chen, L. V. Kuznetsova and I. Ojima, "Recent advances in tumor-targeting anticancer drug conjugates", Bioorg. Med. Chem., 13, pp. 5043-5054, 2005.

[4] S. M. Moghimi, A. C. Hunter and J. C. Murray, "Nanomedicine: current status and future prospects", FASEB J., 19, pp. 311-330, 2005.

[5] H. Maeda, J. Wu, T. Sawa, Y. Matsumura and K. Hori, "Tumor vascular permeability and the EPR effect in macromolecular therapeutics: a review", J. Control. Release, 65 (1-2), pp. 271-284, 2000.

[6] F. Danhier, O. Feron and V. Préat, "To exploit the tumor microenvironment: passive and active tumor targeting of nanocarriers for anti-cancer drug delivery, J. Control. Release", 148 (2), pp. 135-146, 2010.
[7] G. Russell-Jones, K. McTavish, J. McEwan, J. Rice and D. Nowotnik, "Vitamin-mediated targeting as a potential mechanism to increase drug uptake by tumors", J. Inorg. Biochem., 98, pp. 1625-1633, 2004.

[8] C. P. Leamon and J.A. Reddy, "Folate-targeted chemotherapy", Adv. Drug Deliv. Rev., 56, pp. 1127-1141, 2004.

[9] G. Russell-Jones, K. McTavish and J. McEwan, "Preliminary studies on the selective accumulation of vitamin-targeted polymers within tumors", J. Drug Target., 19(2), pp. 133-139, 2011.

[10] S. Chen, X. Zhao, J. Chen, J. Chen, L. Kuznetsova, S. S. Wong and I. Ojima, "MechanismBased Tumor-Targeting Drug Delivery System. Validation of Efficient Vitamin Receptor-Mediated Endocytosis and Drug Release", Bioconjug. Chem., 21, pp. 979-987, 2010.

[11] C. Daglioglu, "Enhancing tumor cell response to multidrug resistance with $\mathrm{pH}$-sensitive quercetin and doxorubicin conjugated multifunctional nanoparticles", Colloids Surf. B Biointerfaces, 156, pp. 175-185, 2017.

[12] C. Daglioglu, "Environmentally responsive dual-targeting nanoparticles: improving drug accumulation in cancer cells as a way of preventing anticancer drug efflux", J. Pharma. Sci., (epub ahead of print) DOI: http://dx.doi.org/10.1016/j.xphs.2017.10.029, 2017.

[13] G. Minotti, P. Menna, E. Salvatorelli, G. Cairo and L. Gianni, "Anthracyclines: molecular advances and pharmacologic developments in antitumor activity and cardiotoxicity", Pharmacol. Rev., 56, pp. 185-229, 2004.

[14] C. Daglioglu and B. Okutucu, "Synthesis and characterization of AICAR and DOX conjugated multifunctional nanoparticles as a platform for synergistic inhibition of cancer cell growth", Bioconjug. Chem., 27, pp. 1098-1111, 2016.

[15] C. Daglioglu and B. Okutucu, "Therapeutic effects of AICAR and DOX conjugated multifunctional nanoparticles in sensitization and elimination of cancer cells via survivin targeting", Pharm. Res., 34, pp. 175-84, 2017. 